\title{
擬似非定常風速下の蒸発フラックス評価 \\ EVALUATION OF EVAPORATION FLUX UNDER QUASI-UNSTEADY WIND VELOCITY
}

\author{
寺崎寛章 ${ }^{1} \cdot$ 福原輝幸 ${ }^{2} \cdot{\text { 門野浩二 }{ }^{3} \cdot \text { 中根和郎 }}^{4}$ \\ Hiroaki TERASAKI, Teruyuki FUKUHARA, Koji KADONO and Kazurou NAKANE
}

\author{
1学生会員 工修 福井大学大学院 工学研究科博士後期課程（广910-8507 福井県福井市文京 3 丁目 9 番地 1 号) \\ 2 正会員 工博 福井大学教授 工学部建築建設工学科（广910-8507 福井県福井市文京 3 丁目 9 番地 1 号） \\ ${ }^{3}$ 正会員 工修 滋賀県警 滋賀県警察科学捜查研究所（广5 520-0106 滋賀県大津市唐崎 1 丁目 34 番地 3 号) \\ 4 正会員 独立行政法人防苂科学技術研究所 水・土砂防災研究部（テ305-0006 茨城県つくば市天王台 3 番地 1 号）
}

The present paper describes a new method to precisely calculate hourly evaporation flux under quasi-unsteady wind velocity using the wind tunnel that can supply a set of high/low speed winds by turns for every set-up period. Soil columns was used for the evaporation experiment and Chao soil and Toyoura standard sand were used for the experiment. The difference in the hourly evaporation flux, $E_{v h}$, became no less than $12-18 \%$ by changing the combination of the high/low speed winds, regardless of the kind of soil, although the average wind velocity, $V_{w m}$, was the same for all the wind-velocity combinations. This fact is attributed to the nonlinearity of the relation between the evaporation coefficient, $\alpha_{v}$, and wind velocity. It is found that $E_{v h}$ calculated using $\alpha_{v}$ for the high and low wind velocities is more accurate than that calculated using $\alpha_{v}$ for $V_{w m}$.

Key Words : quasi-unsteady wind, hourly evaporation flux, evaporation coefficient, chao soil

\section{1.はじめに}

蒸発に関連する問題は土木工学に限っても，水資源の 保全, 農業用水の水管理, 塩害, 路面凍結, 地球・都市 の熱環境などの多岐に亘り, 蒝発量を正確に評価するこ とは, 様々な分野に有益な情報をもたらすことが期待さ れる. 通常, 蒸発量の直接測定(水収支法)にはライシメー タや蒸発パンが用いられる. ライシメータによる計測は 長期観測には有効であるが, 齊藤・山中 ${ }^{1)}$ は降雨時や降雨 直後の蒸発量は極端に上昇もしくは下降傾向があること を示した. また蒝発パンによる計測は，簡易かつ安価で あるが，多くの人的労力を要する。

他の直接測定として, 渦相関法 ${ }^{2-5)}$ は乱流計測から得ら れる蒸発フラックス (瞬間值)の時間積分より蒸発量を計 算し，陸(海)-大気間の顕熱・潜熱輸送のみならず， $\mathrm{CO}_{2}$ などの微量気体の輸送現象解明に利用されている. 測定 に際しては，2成分の風速を検出する必要があるので， 1 方向成分の風速計に比べて, 風速計の据付調整が難しく なる. また, 洞相関法による水蒸気輸送フラックスが, 蒸発面からの蒸発量をどの程度まで反映しているかは検 討の余地があり, 精度向上のためには多点同時測定が必
要となる.

実際には, 種々の気象観測機器から得られるデータを 基に，地表のエネルギ一収支式より間接的に蒸発量を推 定するのが一般的である ${ }^{6)-7)}$. この方法での蒸発量の精度 は言うまでもなく, 気象観測, 地中熱伝導フラックスお よび湿熱の測定精度に依存する。

加えて, 野外観測には多くの制約(電源の確保, 電気の 質, 過酷な気象条件, 地形, 埃, 観測機器の維持・管理) が付きものであり，長期に亘る正確な蒸発量測定は容易 ではない.

さらに, 野外では風速が瞬時に変化するため蒸発量の算 定および誤差の評価を難しくさせる. 例えば, 著者らは豊 浦標準砂を用いた擬似非定常風下(高速と低速の風を繰り 返し送る) の蒸発実験 ${ }^{8)}$ により, 平均風速は同じでも高-低 風速の組み合わせにより, 時間蒸発量に最大 $12 \%$ の違いが 生じることを示した.

そこで，本論文ではこの時間蒸発量の違いの原因を明 らかにするために, チャオソイル(代表的な中国塩害土壌 の一種)および豊浦標準砂を対象として風速が変化する 際の蒸発現象(蒸発の過渡現象)を詳細に調べるとともに, 新たな時間蒸発フラックスモデルを提案する. 


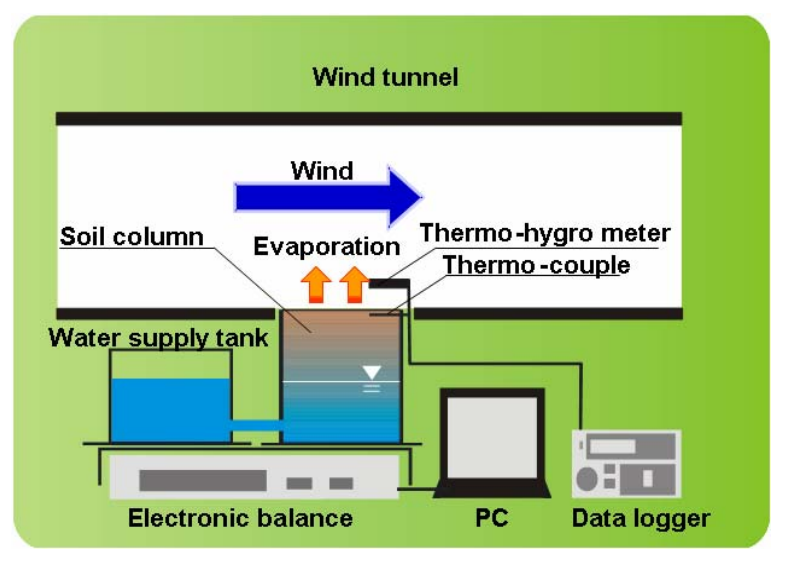

図-1＼cjkstart風洞実験概要

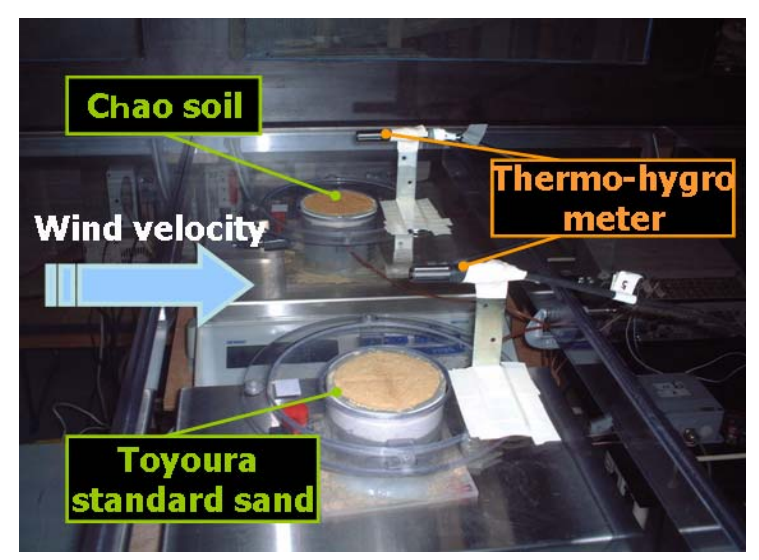

写真-1 実験状況

$$
E_{\text {vh1 }}=3600\left(E_{v}\right)_{60}
$$

ここに, $\left(E_{v}\right)_{60}$ : 式(2)の $\alpha_{v}, D_{a t m}, \rho_{v s u r f}$ おび $\rho_{v a i r}$ に 1 時 間に亘る風速の平均值を適用した時の蒸発フラックスで ある。

これに対して, 後述の 4.2 で示すように, 非線形な $\alpha_{v}$ と $V_{w 0}$ の関係を考慮して, 新しい時間蒸発フラックス $E_{v h 2}$ を提案する. $E_{\mathrm{vh} 2}$ は一定風速期間 $\Delta t$ (分) 毎に蒸発フラック スを計算し，それを 1 時間に亘り積算して得られる.す なわち,

$$
E_{v h 2}=60 \Delta t \sum_{i=1}^{n}\left(E_{v i}\right)_{\Delta t}
$$

ここに， $n=60 / \Delta t, \quad\left(E_{v i}\right)_{\Delta t}:$ 式(2)の $\alpha_{v}, D_{a t m}, \rho_{v s u r f}$ および $\rho_{\text {vair }}$ に $\Delta t$ に亘る風速の平均值を適用した時の蒸発フラッ クスである.

\section{3. 風洞実験概要}

風洞実験は，防災科学技術研究所内の地表面乱流風洞 実験装置(以下, 風洞と記述)を用いて行った. 本実験は, 種々の定常風速における定常蒸発フラックスを求める定 常風速蒸発実験と高風速と低風速を組み合わせた擬似非 定常風速蒸発実験に大別される.

\section{1 実験装置}

風洞実験は, 風洞 (幅 $1 \mathrm{~m}$, 高さ $1 \mathrm{~m}$, 長さ $3 \mathrm{~m})$, 風洞底 面に設置された土壤カラム (内径 $0.075 \mathrm{~m}$, 高さ $0.08 \mathrm{~m}$ の塩 ビ製カラム), $0.01 \mathrm{~g}$ 読みの電子重量計(METTLER TOLED 製), 温湿度計(VAISALA 製), 熱線風速計, 熱電対およ び 2 種類の土壌(チャオソイルおよび豊浦標準砂)により 構成される(図-1 およひ写真-1 を参照). 風速および温 度・湿度は，地表から高さ $0.4 \mathrm{~m}$ までの間で 0.005 0.05m の間隔で計測された. なお, 風洞は風速, 温度および湿 度が自動制御可能である. 
表-1 土壌の物理特性

\begin{tabular}{|c|c|c|}
\hline & チャオソイル & 豊浦標準砂 \\
\hline 飽和透水係数 $k_{\mathrm{sat}}$ & $9.42 \times 10^{-5}(\mathrm{~m} / \mathrm{s})$ & $2.04 \times 10^{-2}(\mathrm{~m} / \mathrm{s})$ \\
\hline 平圴粒径 $D_{50}$ & $0.017(\mathrm{~mm})$ & $0.183(\mathrm{~mm})$ \\
\hline 間隙率 $\varepsilon$ & 0.40 & 0.39 \\
\hline 土壤分類 & シルト質粘土ローム & 砂質土 \\
\hline
\end{tabular}

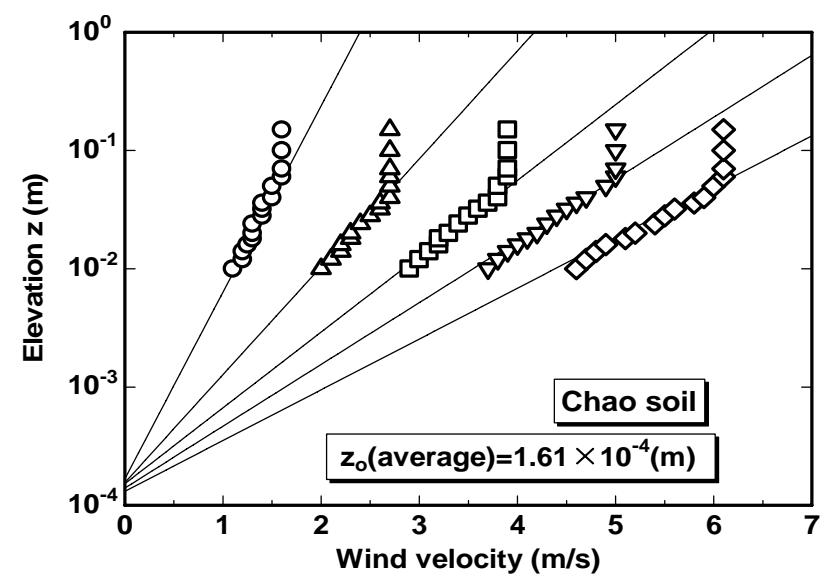

図-2＼cjkstart風速分布(チャオソイル)

また表-1 は，チャオソイルおよび豊浦標準砂の代表的 な物理特性を示す. チャオソイルは豊浦標準砂と違って, シルト質粘度ロームであり，平均粒径は後者のおよそ 1/10である。

\section{2 実験手順および実験条件}

本実験では，カラム内部にチャオソイルを充填密度 $1500 \mathrm{~kg} / \mathrm{m}^{3}$ で，豊浦標準砂を $1600 \mathrm{~kg} / \mathrm{m}^{3}$ でそれぞれ均一に 充填し, 給水カラムを用いて飽和させた後, カラム頂面 と風洞底面が一致するように調整した. カラム頂面から $5 \mathrm{~mm}$ 下に熱電対を挿入し, カラムと電子重量計の上に固 定することにより，土壤表面温度およひ蒸発量をそれぞ れ測定する。また，温湿度計により風洞内の空気温度お よび相対湿度を，熱線風速計により風速を，それぞれ同 時に測定する.

次に，実験条件を述べる．定常風速蒸発実験では 0〜 $6 \mathrm{~m} / \mathrm{s}$ の任意の風速を, 擬似非定常風速蒸発実験では, $0.4 \mathrm{~m} / \mathrm{s}$ と $5.0 \mathrm{~m} / \mathrm{s}, \quad 0.9 \mathrm{~m} / \mathrm{s}$ と $4.5 \mathrm{~m} / \mathrm{s}$ および $1.5 \mathrm{~m} / \mathrm{s}$ と $3.9 \mathrm{~m} / \mathrm{s}$ の3 組(それぞれ Case-A, Case-B, Case-C と呼称)の風速 を選び，実験を行った(表-2 を参照)。なお，各 Case とも 平均風速は同じ $2.7 \mathrm{~m} / \mathrm{s}$ であった．また実験では，各 Case とも高/低風速を 15 分または 30 分毎に瞬時に切り替え,
表-2 実験条件一覧

\begin{tabular}{|c|c|c|c|}
\hline 対象土畩 & \multicolumn{3}{|c|}{ チャオソイルおよび豊浦標淮砂 } \\
\hline 環境条件 & \multicolumn{3}{|c|}{ 温度 $25^{\circ} \mathrm{C}$ 湿度 $50 \%$} \\
\hline 実験ケース & $\begin{array}{c}\text { 低風速 } \\
(\mathrm{m} / \mathrm{s})\end{array}$ & $\begin{array}{c}\text { 高風速 } \\
(\mathrm{m} / \mathrm{s})\end{array}$ & $\begin{array}{c}\text { 平均風速 } \\
(\mathrm{m} / \mathrm{s})\end{array}$ \\
\hline Case-A & 0.4 & 5.0 & 2.7 \\
\hline Case-B & 0.9 & 4.5 & 2.7 \\
\hline Case-C & 1.5 & 3.9 & 2.7 \\
\hline
\end{tabular}

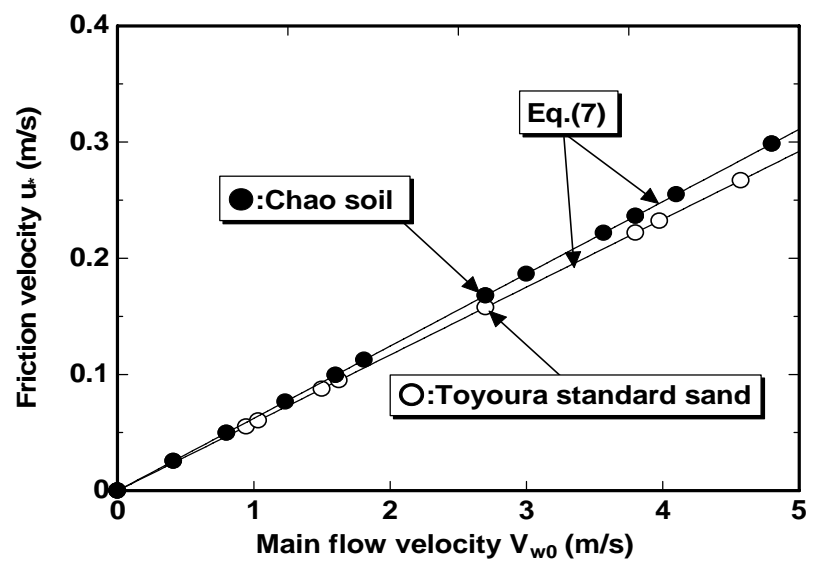

図-3 主流風速 $V_{w 0}$ と摩擦速度 $u_{*}$ の関係 (チャオソイルおよび豊浦標準砂)

風速，土壊表面温度および蒸発フラックスの挙動を同時 に調べた.

\section{4. 実験結果}

\section{1 風速分布}

図-2 にチャオソイル上の風速分布を示す. 高さ $0.05 \mathrm{~m}$ までは以下の式(6)に示すような対数則が成立する. すな わち,

$$
\frac{V_{w}}{U_{*}}=\frac{1}{\kappa} \ln \frac{z}{Z_{0}}
$$

ここに, $\mathrm{z}$ : カラム頂上から鈆直上向きの高さ $(\mathrm{m}), V_{w}$ : 任意の高さの風速 $(\mathrm{m} / \mathrm{s}), \kappa$ : カルマン定数 $(=0.4), \mathrm{z}_{0}$ : 粗 度高さ $(\mathrm{m})$ ，である.

チャオソイルおよび豊浦標準砂の $z_{0}$ はそれぞれ, $1.61 \times$ $10^{-4} \mathrm{~m}, 1.06 \times 10^{-4} \mathrm{~m}$ であり, 大きな差はないことが知れる.

図-3 は $V_{w 0}$ と $u * の$ 関係を示す。両者の間には,

$$
u_{*}=A V_{w 0}
$$

が成立する．ここに比例係数Aは，チャオソイルおよび豊

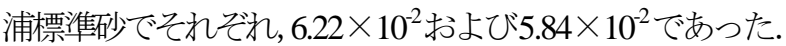




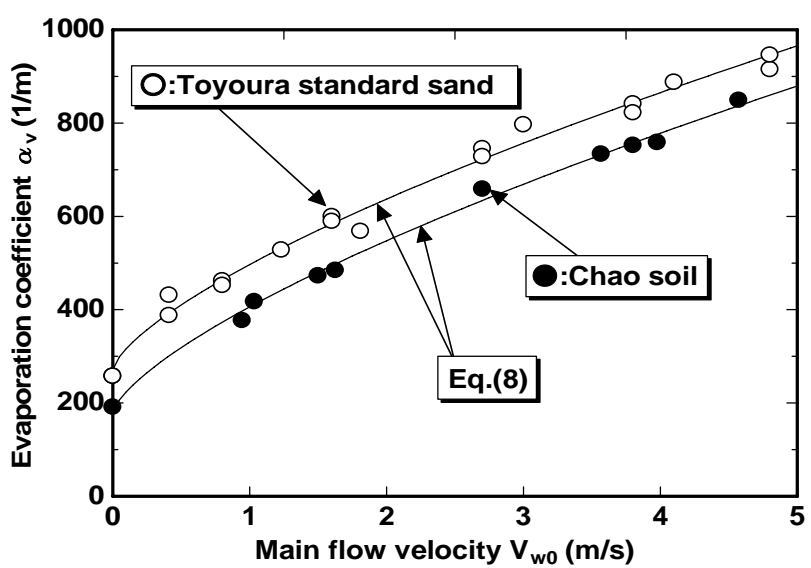

図-4 蒸発係数 $\alpha_{v}$ と主流風速 $V_{w 0}$ の関係 (チャオソイルおよび豊浦標準砂)

表-3 各土壌における係数の值

\begin{tabular}{|c|c|c|}
\hline 係数 & チャオソイル & 豊浦標淮砂 \\
\hline$a$ & 227 & 221 \\
\hline$b$ & 178 & 274 \\
\hline$c$ & 162 & 153 \\
\hline$d$ & 184 & 275 \\
\hline
\end{tabular}

\section{2 蒸発係数と界面ダルトン数の性質}

まず，蒸発係数について考察を行う．図-4 は $\alpha_{v}$ と $V_{w 0}$ の関係を示したものである. チャオソイルおよび豊浦標 準砂ともに， $\alpha_{v}$ は $V_{w 0}$ の低下とともに減少し，特に風速 $1 \mathrm{~m} / \mathrm{s}$ 以下での減少割合が大きい，同じ $V_{w 0}$ に対する豊浦 標準砂の $\alpha_{v}$ はチャオソイルのそれより大きいが，両者の $\alpha_{v}$ は式(8) (図-4 の実線)で表されるように, 共に風速の 0.7 乗 に比例する.

$$
\alpha_{v}=a V_{w 0}^{0.7}+b
$$

ここに，aおよびbは係数であり，各土壤に対して表-3に 示すとおりである. このべき数の值 $(0.7)$ は, 藤本ら ${ }^{10)}$ が アスファルト舗装上の蒸発フラックスと風速の関数で得 られた值と一致する. また, 式(1)に従えば, $C_{E}$ は約 $1.5 \mathrm{~m} / \mathrm{s}$ 以下の風速では，もはや一定值にならないことが分かる.

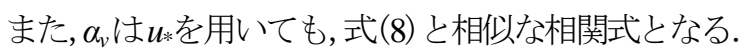
すなわち,

$$
\alpha_{v}=c u_{*}^{0.7}+d
$$

式中の係数 $c$ および $d$ の值も表-3に示す.

次に, Brutsaert ${ }^{11}$ に従って, $D_{a 0}$ と粗度レイノルス数 $R_{e x 0}$ $\left(=u_{*} z_{0} / v\right)$ の関係を調べた. その結果を図-5 に示寸. チ ヤオソイルおよび豊浦標準砂とも $D_{a 0}$ は次式に従う.

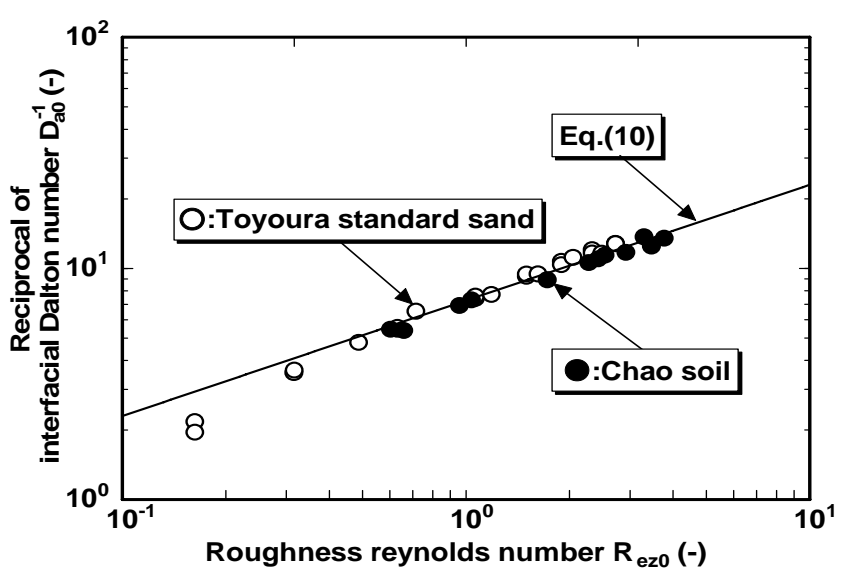

図-5 界面ダルトン数 $D_{a 0}$ と粗度レイノルズ数 $R_{e z 0}$ の関係 (チャオソイルおよび豊浦標準砂)

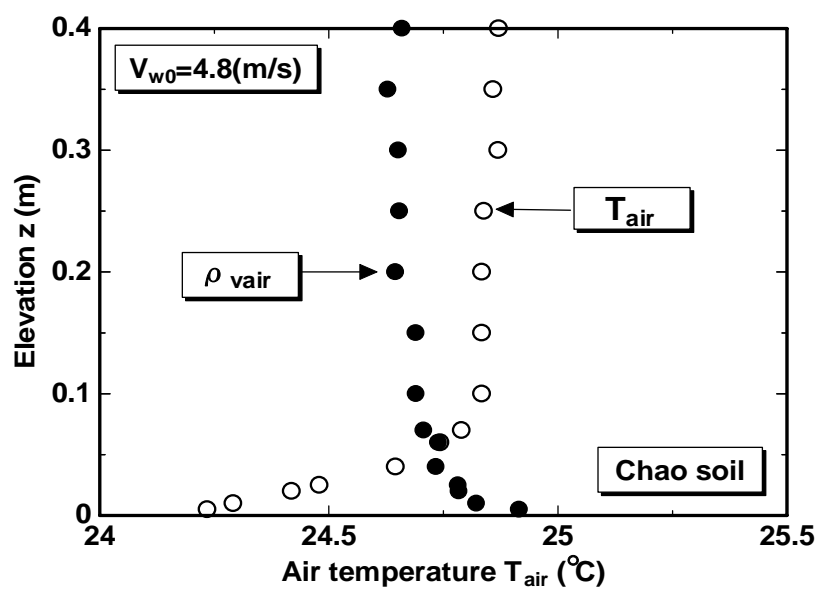

図-6 風洞内の空気温度 $T_{\text {air }}$ と水蒸気密度 $\rho_{v a i r}$ の鉛直分布 (チヤオソイル)

$$
D_{a 0}=a_{0} R_{e z 0}^{-0.5}
$$

ここに, $a_{0}$ は定数であり, $a_{0}=7.27$ となる. ただし, 図 -5 は慣例に従って $D_{a 0}$ の逆数 $\left(D_{a 0}^{-1}\right)$ と $R_{e x 0}$ で表される.また, 実験条件の多くは, 滑面と粗面の遷移域 $\left(0.13<R_{e z 0}<\right.$ 2) ${ }^{11)}$ に属する.

\section{3 風洞内の空気温度および水蒸気密度}

図-6 は $V_{\mathrm{w} 0}=4.8 \mathrm{~m} / \mathrm{s}$ での風洞内の空気温度 $T_{\text {air }}$ と水蒸気 密度 $\rho_{\text {vair }}$ の鉛直分布を示寸. 土壌表面近傍では, 大気から 土壌表面に向かって $\rho_{\text {vair }}$ は増加し, 水面蒸発て観られる水 蒸気密度分布と同じである. 逆に, $T_{\text {air }}$ は土袞表面に向か って減少し, 土壌表面で最小となる。 これは蒝発潜熱に 起因する. また $T_{\text {air }}$ と $\rho_{\text {vair }}$ の境界層(拡散層) 厚は同程度で あり, 式(2)のバルク式には地表面より $0.2 \mathrm{~m}$ 以上の $\rho_{\text {vair }}$ を代表值として用いる. また，ここには示さないが， $\rho_{\text {vair }}$ は風速に依存することなく, どの実験ケースも概ね同じ 值 $\left(1.13 \times 10^{-2} \mathrm{~kg} / \mathrm{m}^{3}\right)$ であった. 


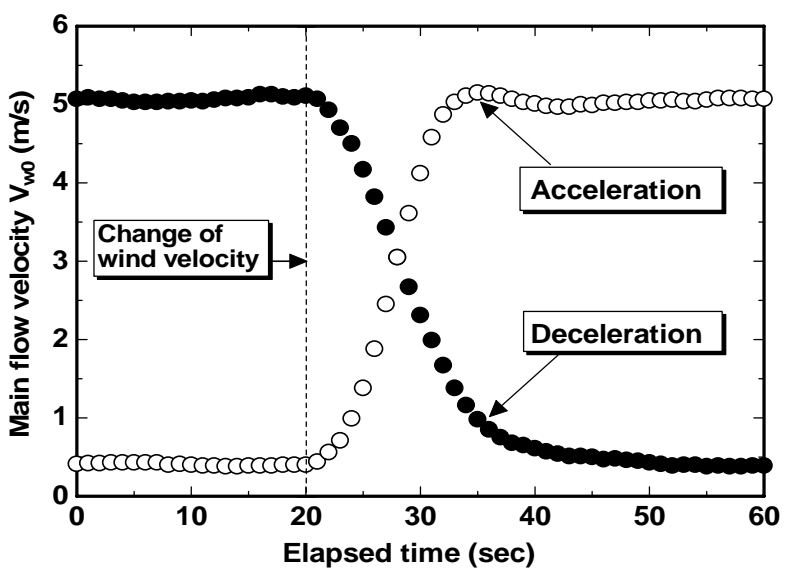

図-7 風速の過渡変化(Case-A)

\section{4 擬似非定常蒸発の過渡現象}

図-7 はチャオソイルの Case-A の実験において, 経過時 間20秒の時点で瞬時に風速を切り替えた時の風速の経時 変化(風速の過渡変化)を表寸. なお, 計測位置は地表面 から $0.1 \mathrm{~m}$ の高さである. 風速の回復は減速よりも加速の 方で少し速い上うであるが，せいぜい 30 秒以内である.

図-8 は, $\Delta t=15$ 分における実験開始 30 分から 120 分ま での3サイクルに亘るチャオソイルの $T_{\text {suf }}$ の経時変化を, Case-AおよびCase-Cに対してそれぞれ示したものである. $T_{\text {surf }}$ は低風速期間より高風速期間で低温となる. これは蒸 発潜熱が高風速期間で大きいことに起因寸る. 従って, 風速差 $\Delta V_{w}$ の大きなCase- $A\left(\Delta V_{w}=4.6 \mathrm{~m} / \mathrm{s}\right)$ の $T_{\text {surf }}$ の振幅は, $\Delta V_{w}$ の小さなCase-C $\left(\Delta V_{w}=2.4 \mathrm{~m} / \mathrm{s}\right)$ のそれより大きくなる.

また加速および咸速に関係なく, 風速が変化した直後 に $T_{\text {sur }}$ は急激に変化し，その後は徐々に一定值に漸近寸 る. $T_{\text {surf }}$ が一定值に達する時間すなわち回復時間は, 温度 振幅の小さな Case-C の方で早く, 約 8 分である. 一方, Case-A の回復時間は約 10 分となる.

以上より， $T_{\text {sur }}$ の回復時間は風速のそれに比べて1オー ダ長い.

\section{5 積算蒸発量}

図-9 は, $\Delta t=30$ 分におけるチャオソイルの Case-A およ び Case-C に対する単位面積当たりの積算蒸発量 $\Sigma Q_{e v}\left(\mathrm{~kg} / \mathrm{m}^{2}\right)$ の経時変化を, 実験開始から 150 分に亘り示 したものである. $\Sigma Q_{e v}$ の勾配(蒸発フラックス)は低風速 期間よりも高風速期間で相対的に大きい. また, Case-C の $\Sigma Q_{e v}$ は, Case-A のそれより大きく, 2 つの $\Sigma Q_{e v}$ の差は 時間とともに広がる.この $\Sigma Q_{e v}$ の差の広がりは低風速期 間で顕著である. 他のケースも含め Case-A のように風速 振幅の大きな場合（その際，低風速が $1.0 \mathrm{~m} / \mathrm{s}$ 以下）の $\Sigma Q_{e v}$ は, Case-C のように風速振幅の小さな場合(その際, 高/ 低風速が共に $1.5 \mathrm{~m} / \mathrm{s}$ 以上)のそれより小さくなる. ちなみ に図-9 の場合, 経過時間 150 分における Case-A の $\Sigma Q_{e v}$

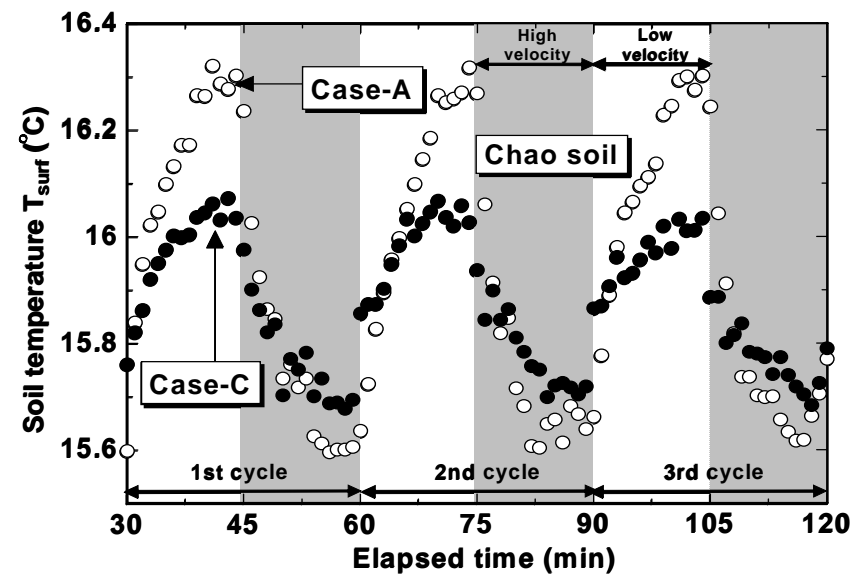

図-8 地表面温度 $T_{\text {surf }}$ の経時変化(Case-A およびCase-C) (チャオソイル)

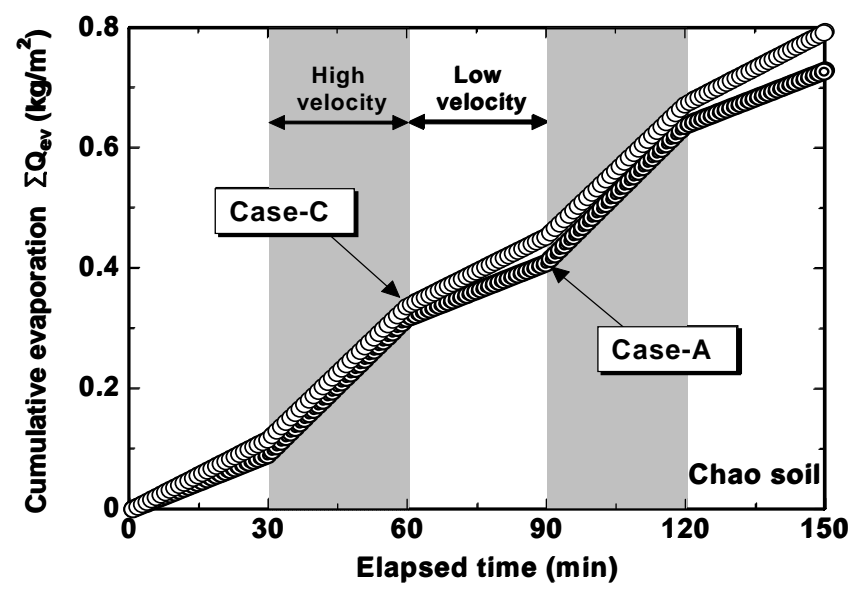

図-9 積算蒸発量の経時変化(Case-A およびCase-C) (チヤオソイル)

は, Case-Cのそれの0.82 となる. 結果として, チャオソ イルの $E_{\mathrm{vh}}$ は平均風速が同じでも, 最大で $18 \%$ 違いが あり, 豊浦標淮砂のそれ(12\%)以上となった。

\section{5. 時間蒸発フラックスの計算値と実測值の比較}

図-10 は，時間蒸発フラックスの計算值 $E_{\mathrm{vh1}}($ 式(4))お よび $E_{v k 2}\left(\right.$ 式(5)) と実測值 $E_{v o b s}\left(\right.$ 最終 $\Sigma Q_{e v} /$ 経過時間 $($ 分 $) \times$ 60)の比較結果を示寸. なお, 同図には, $\Delta t=15$ 分および $\Delta t=$ 30 分の結果が併示される.

土壌に関係なく, 全てのケースで $E_{v h 2}$ は $E_{v h 1}$ よりも $E_{v o b s}$ に近い值となる. $E_{\text {vh } 1}$ と $E_{\text {vobs }}$ の最大誤差はチャオソイルで $12 \%$ ，豊浦標準砂で $8 \%$ であるが， $E_{\mathrm{vh2}}$ と $E_{\text {vobs }}$ の最大誤差 はチャオソイルで $4 \%$ ，豊浦標潐砂で $3 \%$ であり， $E_{v 22}$ の 最大誤差は $E_{v h 1}$ のそれより小さい. なお， $E_{\mathrm{vh2}}$ の誤差の原 因は風速変化に伴う $T_{\text {suf }}$ の過渡現象が，式(5)に組み込ま れていないことに起因すると考えられる.

また, $E_{\mathrm{vh1}}$ と $E_{\mathrm{vh2}}$ の差が大きいのは, 高風速と低風速の 風速差が大きく, かつ $1.0 \mathrm{~m} / \mathrm{s}$ 以下の低風速を含む場合 


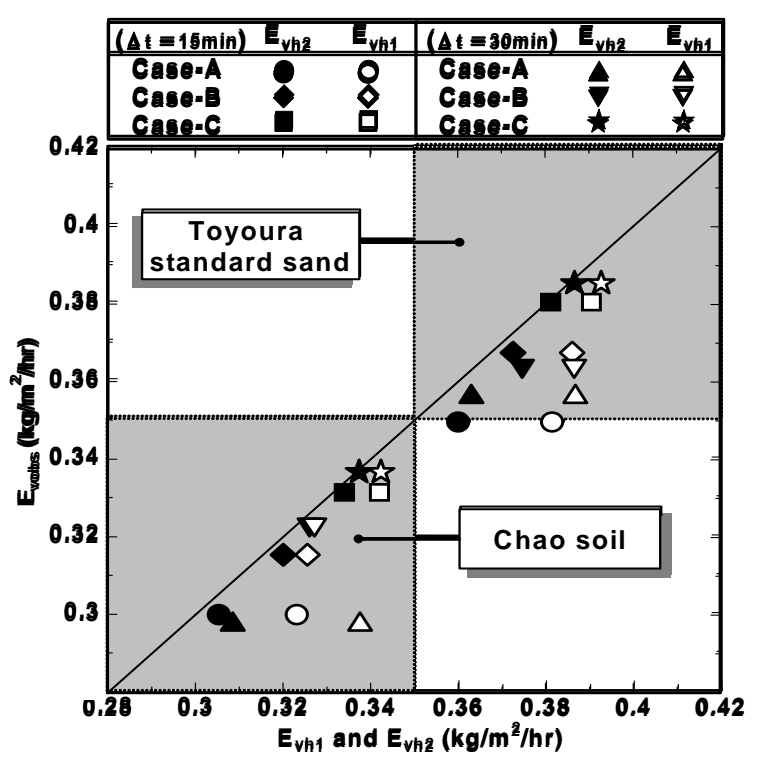

図-10 時間蒸発フラックスの計算值 $E_{v h 1}$ および $E_{v h 2}$ と 実測值 $E_{\text {vobs }}$ の関係(チャオソイルおよび豊浦標準砂)

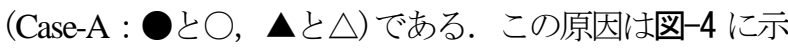
したような $\alpha_{v}$ と $V_{w 0}$ の非線形性にある. 従って， $\alpha_{v}$ と $V_{w 0}$ の関係が線形に近い $V_{w 0}>1.5 \mathrm{~m} / \mathrm{s}$ の高風速と低風速の組み 合わせ (Case-C : $\mathbf{⿱ 亠 䒑}$ 小さくなる.

また，チャオソイルでは Case-B および Case-C におい て,豊浦標準砂では Case-A およびCase-C において, $\Delta t=30$ 分の $E_{\text {vobs }}$ の方が $\Delta t=15$ 分のそれより僅かに大きいが，実 験の精度を考慮すれば無視できる程度である. チャオソ イルの場合, $\Delta t=15$ 分における $E_{v h 2}$ と $E_{\text {vobs }}$ の最大誤差は $2 \%($ Case-A) で, $\Delta t=30$ 分のそれは 4\% (Case-A) であり, 両者の差異はそれぞれ小さい. 従って本実験においては, $\Delta t$ が $E_{\mathrm{vh2}}$ に及ぼす影響は小さいと考えられる，なお，豊 浦標準砂においても同様の傾向が認められる.

\section{6. おわりに}

非定常風速下の蒸発量の評価方法を構築する前段階と して, 高風速と低風速が繰り返し発生するような擬似非 定常風速下の蒸発フラックスの特性を明らかにするため に，風洞内で蒸発実験を行った。この実験結果を基に， 時間蒸発フラックスの計算精度を上げるための新モデル （式(5)）を提案し, 従来モデル(式(4)）と比較を行った. 本研究で得られた主要な結論を以下に列挙する.

（1）土壌の種類に関わらず，高風速と低風速を繰り返し 受ける際の時間蒸発フラックスは, たとえ同じ平均 風速であっても，風速の組み合わせによっては $10 \%$ 以上の差異が生じる.

（2）（1）の原因は蒸発係数と主流風速の非線形な関係に 起因寸る. 特に, この非線形性は主流風速が $1.5 \mathrm{~m} / \mathrm{s}$ 以下で顕著となる.
（3）チャオソイルおよび豊浦標準砂に関して, 界面ダル トン数 $D_{a 0}$ と粗度レイノルズ数 $R_{e x 0}$ の関係は, 同じ相 関式で与えられ，本実験内の範囲内において $D_{a 0}$ は $R_{e \geq 0}$ の- 0.5 乗に比例する.

（4）風速変化に伴う蒸発フラックスの過渡変化は, 風速 よりも地表面温度の回復時間に規定される.

（5）高風速と低風速毎に蒸発フラックスを積算していく 新モデルは，単純に時間平均風速を用いて蒸発フラ ックスを計算する従来モデルよりも, 時間蒸発フラ ックスの計算精度が良い(誤差は約 $1 / 3 \sim 1 / 2$ になる).

(6) 従来モデルでは, $1.0 \mathrm{~m} / \mathrm{s}$ 以下の低風速と $1.5 \mathrm{~m} / \mathrm{s}$ 以上 の高風速が繰り返し発生するような場合, 時間蒸発 フラックスは, 土鎄の種類に関わらず $10 \%$ 以上の誤 差が生じる可能性がある.

\section{参考文献}

1）齊藤誠, 山中勤 : ウェイングライシメータによる蒸発散量 長期観測データの解析とクオリティーコントロール, 筑波 大学陸域環境研究センター報告, No.6, pp.53-62, 2005.

2) 玉川一郎 : 渦相関法での乱流フラックス観測=実例と解析 法=，超音波，Vol.10, No.11, pp.24-27, 1998.

3）成松明, 田中健路, 森本剣, 滝川清: 乱流渦相関法を用い た有明干潟上の地表面フラックス直接観測, 海岸工学論文 集, Vol.52, No.2, pp.1081-1085, 2005.

4) 町村尚: 細線熱電対乾湿計を用いた洞相関法による降雨時 の顕熱・潜熱フラックス測定, 農業気象, Vol.54, No.4, pp.315-322, 1998.

5）三枝信子，村山昌平，山本晋，近藤裕昭 : 渦相関法による $\mathrm{CO}_{2} \cdot \mathrm{H}_{2} \mathrm{O}$ フラックスの長期測定, 日本気象学会大会講演予 稿集, No.74, pp.146, 1998.

6) 近藤純正: 裸地面蒸発の季節変化, 水文・水資源学会誌, Vol.7, No.5, pp.378-385, 1994.

7）木村玲二, 高山成, 神近牧男, 松岡延浩: 黄土高原におけ る土壌水分と熱収支一土壌 3 層モデル内のパラメーターの決 定とモデル計算の結果-, 農業気象, No.60(1), pp.55-65, 2004.

8）門野浩二, 福原輝幸, 寺崎寬章, 中根和郎 : 擬似非定常送 風下における土壌表面からの時間蒸発フラックス-豊浦標 淮砂の場合, 第 60 回土木学会年次学術講演会講演概要集, II-028, 2005.

9）近藤純正: 水環境の気象学-地表面の水収支・熱収支-, 朝 倉書店, pp.108-109, 1994.

10）藤本明宏, 福原輝幸, 渡邊洋, 佐藤威, 根本征樹, 望月重 人, 岸井徳雄 : 乾燥, 湿閏, 氷板および圧雪路面と大気と の間の熱・水蒸気移動, 日本雪工学会誌, Vol.22, No.3, pp.14-22, 2006.

11) Brutsaert, $W$ :Evaporation into the Atmosphere, Kluwer Academic publishers, Netherlands, pp.92-95,1991.

(2007.9.30 受付) 